\title{
Synthesis of 5-spirocyclohexyl-2,4-dithiohydantoin derivatives: a potential anti-leishmaniasis agent
}

\author{
Abdel-Sattar S. Hamad Elgazwy - Saad R. Atta-Allah • \\ Sherif M. A. S. Keshk
}

Published online: 12 February 2009

(C) Springer-Verlag 2009

Erratum to: Monatsh Chem (2009) 140:243-249

DOI 10.1007/s00706-008-0063-9

The original version of this article unfortunately contained a mistake. The spelling of the co-authors' name was incorrect, it should read: Saad R. Atta-Allah.

The online version of the original article can be found under doi:10.1007/s00706-008-0063-9.

A.-S. S. Hamad Elgazwy ( $ه)$ · S. R. Atta-Allah Department of Chemistry, Faculty of Science,

University of Ain Shams, Abbassia, 11566 Cairo, Egypt

e-mail: aselgazwy@yahoo.com; hamad@asunet.shams.edu.eg;

elgazwy@usa.com

S. M. A. S. Keshk

Department of Basic Science,

Institute of Environmental Studies and Research,

University of Ain Shams, Abbassia, 11566 Cairo, Egypt 